\title{
Honorary Membership in the Life of Black Greekdom
}

\author{
Judson L. Jeffries ${ }^{1}$
}

Accepted: 10 September 2021 / Published online: 25 October 2021

(C) The Author(s), under exclusive licence to Springer Science+Business Media, LLC, part of Springer Nature 2021

Historically, honorary membership in Black Greek-Letter fraternities and sororities has been reserved for those men and women who have distinguished themselves in their chosen fields of endeavor, as well as exemplified the organization's ideals, values, and principles in both their personal and professional lives. Successful candidates have not been required to be college graduates or to have even attended college, for that matter. Traditionally, honorary membership has not been granted often or haphazardly, nor should it be. Relatively few individuals will ever have such a distinction bestowed on them during their lifetimes. Recently-meaning in the last 15 years or so, I have noticed that honorary membership has come under fire in both print and online media. Then again, perhaps honorary membership has always been a subject of debate, unbeknownst to me. Be that as it may, recent conversations with friends, associates, and colleagues about honorary membership all feature the same issues-worthiness and transparency of process_-prompting this writer to give the matter some thought and put pen to paper. Having said that, what exactly are the goals and objectives of honorary membership? What purpose does honorary membership serve? Is the objective to select men and women, who due to their fame, will bring a certain level of notoriety to an organization that is already known the world over? Is honorary membership reserved only for the rich and famous? Is the objective to ingratiate oneself with men and women of means for fundraising purposes? Is the purpose to select men and women whose political clout will position the organization to make inroads into previously impregnable quarters of varying industries? Is it about ushering in a certain number of celebrities for the purposes of bragging rights vis-a-vis the other historically Black fraternities and sororities? Is the intention to genuinely acknowledge those men and women who best exemplify the organization's values and mores, meaning who have demonstrated in their works and deeds the organization's character and constitution? Or is it to publicly recognize the achievements and personal sacrifices of those to whom the race owes a debt of gratitude? These nine questions merit our attention.

Judson L. Jeffries

jeffries.70@osu.edu

1 Department of African American and African Studies, The Ohio State University, Columbus, OH 43210, USA 
Candidates for honorary membership should be subjected to close scrutiny and undergo a rigorous vetting process. In other words, the honor should be earned, not given. It should also not be taken lightly. Only the chosen few are deserving of such an honor. When colleges and universities award honorary doctorates, for example, there is a certain expectation on the part of the awardee, and both parties understand that. Upon granting and being granted honorary membership in any one of the Divine Nine, it needs to be understood by the granting entity, meaning that fraternity/sorority, as well as the recipient, that from that day forth, the two will embark upon a lifetime journey of reciprocity grounded in service, benevolence, and a commitment to enhancing the life chances of our people, wherever they may be in the world. This is not to exclude others or to be understood that the commitment to uplift other Black people is to be done at the expense or to the detriment of nonBlack people, but it should be made clear that our first priority is the well-being of men, women, and children who look like us. "Up you mighty race, accomplish what you will!", exhorted the Pan-Africanist Marcus Garvey.

A college degree is not a requirement for honorary membership in any of the nine organizations, from what I can tell, but perhaps it should be, unless of course a prospective candidate has exhibited scholarly achievement by distinguishing him or herself in letters as an author of books, articles, or other literary efforts. Otherwise, should someone for whom a college education may not have been a priority be considered for honorary membership? To be fair and balanced, not everyone is of the manner born, nor does everyone come from a family for which a college education is feasible. However, if said person has achieved the kind of financial security that is commonly associated with those typically granted honorary membership, at some point, tuition costs should not have precluded pursuit of a college degree.

Black fraternities and sororities have a rich tradition of honorary membership. Take, for example, the Omega Psi Phi Fraternity, Inc., the only member of the Divine Nine in whose history I am steeped. Special honorary membership mentions include Dr. Ernest E. Just, US Army Colonel Charles R. Young, and Dr. Carter G. Woodson, whose exploits are widely known within Omega circles and well documented in the annals of history. Not as well-known, but no less impressive in achievement and stature are Professors G. David Houston (1880-1940) of Tuskegee and Howard Universities and William Pickens (1881-1954), who taught at Talladega College for 10 years before assuming the position of Dean of Academics at Morgan State College. ${ }^{1}$ Aramis Fouche (1904-2001), a civil rights activist and owner of California's oldest Black funeral home, was also an honorary member. Additionally, he founded two banks for the purposes of helping Blacks purchase homes and launch businesses in and around the Bay Area. Count Basie and Roland Hayes were also honorary members. ${ }^{2}$ Neither Basie, Hayes, nor Fouche were college graduates, but an argument could be made that a college education was not as readily attainable for Black men of their generation, as it later would become.

\footnotetext{
${ }_{1}$ Houston is the first African American born in Cambridge, Massachusetts, and educated in the Cambridge public school system to earn a degree from Harvard College.

2 In 1974, Basie was awarded an Honorary Doctorate of Music from Monmouth College in New Jersey. In 1966, Hayes was awarded an Honorary Doctorate of Music from the Hartt School of Music at the University of Hartford. As a younger man Hayes had studied at Fisk but was kicked out for varied reasons.
} 
It should be noted that for much of the Omega Psi Phi fraternity's history, honorary membership was seemingly granted infrequently and with a great deal of discernment. Some are of the opinion that seems to have changed somewhat in recent years. This is not to suggest that the floodgates have opened, but the selective use of honorary membership has seemingly not been employed as judiciously in recent decades, as was the case in earlier periods. The reasons for this are unclear. Moreover, whether or not that is a good thing is a matter of debate. It is a fact of life that honorary membership in many organizations is not without its politics; Black Greek Letter organizations are no exception. The old adage, "Sometimes it's not what you know, but who you know" seems appropriate here. There have undoubtedly been cases where personal relationships have trumped individual merit. On those [I hope] rare occasions, I still cannot help but wonder whether or not we compromise the integrity of the fraternities and sororities that the men and women on whose shoulders we stand strove so hard to bring into existence. As a son of Omega, I am especially mindful of this given, dare I say, the chilly reception that Professor Ernest E. Just, Edgar A. Love, Oscar J. Cooper, and Frank Coleman received when they approached Howard University's Black administration about launching an organization for Negro men. Undaunted, in the end, the four men prevailed, but not without drama of varying kind.

Readers will be interested to know that honorary membership does not exist in the Alpha Phi Alpha and Kappa Alpha Psi fraternities. Alpha Phi Alpha discontinued the practice years ago, but before doing so, it extended the honor to former US Senator (Minnesota) and presidential candidate Hubert H. Humphrey. Phi Beta Sigma did something equally curious with Bill Clinton. I suppose Toni Morrison's inexplicably dubbing Clinton as the first Black president was all the endorsement that Phi Beta Sigma needed to reach out to a man whose presidential administration did as much to ravage Black communities as either of the two previous Republican presidential administrations. Fortunately, no faux pas of that magnitude has ever been committed by The Omega Psi Phi Fraternity, Inc. Nevertheless, perhaps it is time that the fraternities and sororities in which honorary membership still exists, bear in mind the following questions: What purpose does it serve? How does honorary membership further the goals and objectives of the organization? It goes without saying that recognizing on whose broad shoulders we stand, should to some extent, drive our decision making process and guide our moral compass. In the end, placing honorary membership under close scrutiny is a good thing, as it may produce a more transparent and well thought out statement of purpose. On the other hand, it may prompt its examiners to conclude that honorary membership is a relic that has outlived its usefulness.

Publisher's Note Springer Nature remains neutral with regard to jurisdictional claims in published maps and institutional affiliations. 